Religare, ISSN: 19826605, v.16, n.1, agosto de 2019, p.170-206.

\title{
Carismáticos, Política e Conservadorismo Social
}

\author{
Charismatic, Politics and Social Conservatism
}

\author{
Emerson José Sena da Silveira ${ }^{1}$ \\ Vinicius Manduca ${ }^{2}$ \\ Marcos Vinicius de Freitas Reis ${ }^{3}$
}

\section{Resumo}

O presente artigo tem por objetivo analisar o comportamento político dos parlamentares apoiados pela Renovação Carismática Católica na atual conjuntura da política brasileira. Foram feitas entrevistas com parlamentares e lideranças para entender como o referido movimento católico se organiza internamente para o apoio a determinadas candidaturas e seus posicionamentos políticos. Em linhas gerais, o artigo também aborda questões relativas as relações de poder que ocorrem em diversos espaços da sociedade brasileira, discutindo e tecendo considerações acerca do processo de construções de diálogos entre os católicos carismáticos e evangélicos no cenário político brasileiro. Bem como entender de que formas se configuram o embate de ideias diferentes e retratam grupos religiosos que não são ouvidos nos setores da vida pública brasileira.

Palavra Chave: Religião e Política; Igreja e Estado; Catolicismo e Politica

\footnotetext{
1 Antropólogo e Doutor em Ciência da Religião pela Universidade Federal de Juiz de Fora. Professor do Departamento de Ciência da Religião da Universidade Federal de Juiz de Fora, Minas Gerais. E-mail: emerson.pesquisa@gmail.com

2 Doutorando em Sociologia pelo Programa de Pós-Graduação em Sociologia da Universidade Federal de São Carlos (UFSCar). Pesquisador do Núcleo de Estudos de Religião, Economia e Política (NEREP) e do Centro de Estudos Políticos, Religião e Sociedade (CREPESUNIFAP).email: vimanduca@gmail.com

${ }^{3}$ Professor da Universidade Federal do Amapá (UNIFAP) do Curso de Graduação em Relações Internacionais. Professor do Mestrado Profissional Ensino de História (PROFHIST - UNIFAP). Membro do Núcleo de Estudos de Religião, Economia e Política (NEREP-UFSCAR/CNPq). Pesquisador do Observatório em Direitos Humanos da Amazônia (OBADH-UNIFAP/CNPq), Líder do Centro de Estudos Políticos, Religião e Sociedade (CEPRESUNIFAP/CNPq). E-mail para contato: marcosvinicius5@yahoo.com.br
} 
Religare, ISSN: 19826605, v.16, n.1, agosto de 2019, p.170-206.

\begin{abstract}
This article aims to analyze the political behavior of the parliamentarians supported by the Catholic Charismatic Renewal in the current conjuncture of Brazilian politics. Interviews were conducted with parliamentarians and leaders to understand how the aforementioned Catholic movement organizes itself internally to support specific candidacies and political positions. In general terms, the article also addresses issues related to the power relations that take place in diverse spaces of Brazilian society, discussing and weaving considerations about the process of constructing dialogues between charismatic and evangelical Catholics in the Brazilian political scene. As well as understanding the ways in which the confrontation of different ideas takes shape and portray religious groups that are not heard in the Brazilian public life sectors.
\end{abstract}

Keyword: Religion and Politics; Church and State; Catholicism and Politics

\title{
Introdução
}

É crescente a importância da questão religiosa na política nacional. Diante do protagonismo dos evangélicos pentecostais, outros grupos religiosos buscaram também uma forte atuação com base em parâmetros similares de estratégias. Esse seria o caso da Renovação Carismática Católica (RCC), movimento leigo com diversas origens (ecumênicas, universitárias, urbanas, pentecostais) e abrigado por João Paulo II como uma das formas de reposicionar as forças internas do catolicismo (PIERUCCI, PRANDI, 1996; PRANDI, 1997).

Se no começo a RCC focou na introspecção, no exercício de carismas espirituais, numa ação mais religiosa, hoje o movimento desenvolveu grandes articulações sociais e busca de representatividade política através de estratégias 
Religare, ISSN: 19826605, v.16, n.1, agosto de 2019, p.170-206.

pré-determinadas entre formas de campanha e atuação (CARRANZA, 2000; SILVEIRA, 2008; MARIANO, 2011).

A pluralidade representativa do sistema eleitoral legislativo brasileiro permite que grupos específicos alcancem cargos eletivos. Por isso a preferência de denominações e movimentos religiosos com forte capacidade de agrupamento, construindo dessa forma um conglomerado religioso no congresso nacional e assembleias legislativas pelo país (MACHADO, 2000 MACHADO, 2004, MACHADO, 2006, MACHADO, 2012; MARIANO, 2005, 2011). Porém, a importância religiosa vem crescendo também para cargos executivos. De forma direta - como o caso de Marcelo Crivella, cantor gospel membro da Igreja Universal do Reino de Deus, eleito prefeito da cidade do Rio de Janeiro - o apoio grupos religiosos, tem sido cada vez mais caro para eleições do executivo.

Soma-se a isso, um conservadorismo moral crescente (MANDUCA, 2015), devido a questões como a legalização de drogas, homossexualidade e a interrupção voluntária da gravidez são tidas como de extrema importância e com necessidade de serem combatidas (MACHADO, 2000; 2004; 2006; 2012; 2015; 2016).

Sobre esse cenário que o presente texto se debruça, analisaremos as formas e estratégias de fazer política da RCC, seus apoios e articulações, destacando o órgão responsável pelo estabelecimento de seu posicionamento, o Ministério de Fé e Política e as questões atinentes a temática do livro, a questão da intolerância, tomando, por exemplo, a questão do aborto para exemplificar a atuação do movimento.

\section{O comportamento politico dos carismáticos nas eleições e campanhas desde $\mathbf{2 0 1 0}$}


Religare, ISSN: 19826605, v.16, n.1, agosto de 2019, p.170-206.

A partir das eleições de 2010, em especial, identificamos uma aproximação entre carismáticos e evangélicos pentecostais em questões relativas à política, sobretudo na militância em torno de questões morais e no conflito aos candidatos de esquerda e extrema esquerda, que defendem pautas morais menos conservadoras (REIS, 2016; SOFIATI, 2011; SOUZA, 2012; PROCÓPIO, 2012) $)^{4}$. No segundo turno, ambos os grupos religiosos se uniram na tentativa de derrotar a candidata petista Dilma Rousseff, argumentando que ela defendia o aborto e o casamento gay. Houve uma guerra de polarizações, que continua hoje em outros eixos. A então candidata, ungida pelo presidente Lula, num processo interno com pouca democracia interna, tentou se aproximar dos carismáticos e evangélicos a partir de políticos centralistas que chegaram a levá-la a missas na Canção Nova, uma das mais poderosas comunidades católico-carismáticas, e a grandes eventos evangélicos. Não obstante, as estratégias de aproximação foram distribuídos panfletos ácidos e críticos em templos e eventos católico-evangélicos e foi feita uma ampla movimentação contrária nas redes sociais e em programas de Rádio/TV (PROCÓPIO, 2012).

Nas eleições de 2014, quando a então Presidente da República, Dilma Rousseff, tentava a reeleição, após um tumultuado processo eleitoral, novamente parcelas de carismáticos e evangélicos, mas não todos os grupos, se uniram no combate contra a sua vitória (REIS, 2016). Viu-se proclamar, em alguns grupos de oração, missas e eventos de massa que, quem votasse em Dilma, estaria excomungado da Igreja Católica (REIS, 2016). Houve também o afastamento de lideranças que ocupavam cargos de direção em movimentos católicos, pastorais ou em outras entidades católicas por suas posições favoráveis às propostas da candidata petista (REIS, 2016).

No ano de 2015, nos protestos massivos contra o governo de Dilma, houve apoio de grupos carismáticos, católicos e evangélicos. No ano de 2016,

\footnotetext{
${ }^{4}$ Há toda uma relação longa entre política, espaço público e catolicismo que, por conta de nossas opções e do tamanho do texto, não poderemos trabalhar. Mas, fica aqui a lembrança.
} 
Religare, ISSN: 19826605, v.16, n.1, agosto de 2019, p.170-206.

alguns parlamentares carismáticos e evangélicos se uniram para aprovar o processo de impeachment da presidente. A articulação entre católicos e evangélicos tornou-se bem próxima na política, em função das pautas conservadoras em ascensão. Havia dificuldades de aproximação em função de diferenças doutrinárias e por não haver motivos pragmáticos para o trabalho conjunto. Sempre houve um sentimento de antiprotestantismo, demonstrado nas orientações da coordenação nacional dos carismáticos. Havia recomendação para que se evitassem músicas evangélicas nos eventos e que as formações fossem fundamentadas em apenas fontes católicas. Houve também proibição de músicos, palestrantes ou formadores evangélicos em eventos carismáticos (REIS, 2016).

No entanto, no que concerne às questões políticas, houve intensa aproximação, o que pode ser explicado pelo fato de ambos os grupos religiosos visualizarem um "denominador comum" na política partidária. Perceberam que defendem valores comuns e que, se trabalharem juntos, a possibilidade de evitar a aprovação de projetos laicistas e menos conservadores é maior. Isso pode ser observado na orientação dada no Encontro Nacional de Formação, em uma das palestras:

Outro ponto importante ecumenismo, paremos de ficar com picuinha com os irmãos cristãos, paremos de competir com aqueles que estão fazendo o mesmo que nós, paremos de falar mal do evangélico, porque enquanto nós brigamos entre nós o paganismo e o secularismo está tomando o mundo, o Senhor pede AMOR, o Senhor pede UNIDADE, o Senhor pede que você ame aquele irmão que tá em outra igreja ${ }^{5}$.

Na fala acima, percebe-se a necessidade de trabalhar com outros grupos, a exemplo dos evangélicos que possuem a mesma bandeira de ideia dos carismáticos. Esse posicionamento é compreensível quando observa-se a

${ }^{5}$ Fragmento da Palestra proferida por Marizete Martins no Encontro Nacional de Formação da RCC Brasil em 2014. Foi membro do conselho nacional da RCC Brasil 
Religare, ISSN: 19826605, v.16, n.1, agosto de 2019, p.170-206.

acentuada queda da influência da Igreja Católica na política brasileira, pois com o crescimento de outros grupos religiosos e não religiosos na política é natural que o catolicismo perdesse espaço. Uma das maneiras encontradas pelos católicos para se manterem presentes nas disputas políticas e evitarem a perda de privilégios é trabalhar em conjunto com os evangélicos em torno das temáticas defendidas por essa instituição, garantindo a presença no espaço público e estatal.

O Professor Felipe de Aquino, como assim denomina-se um dos maiores líderes da comunidade Canção Nova, apresentador da emissora, afirmou que os católicos precisam aprender com os evangélicos a fazer política, aprender a apoiar candidatos, a usar mais as mídias e as redes sociais na defesa dos valores católicos, ter mais poder de mobilização para pressionar os parlamentares a não votarem em projetos do aborto, casamento gay, eutanásia, dentre outros temas (MACHADO, 2012; 2015; 2016). Em suma, criar a cultura de profissionalização das diversas formas de participação política.

Segundo lideranças carismática, a CNBB e vários bispos não estão cumprindo o seu papel de articuladores de seus fiéis contra a "cultura de morte" (entende-se por este termo todos os projetos que são favoráveis ao aborto e contrários ao modelo de família entre homem e mulher, ao ensino religioso confessional, dentre outros).

Na visão de líderes carismáticos, o episcopado católico deveria alertar a

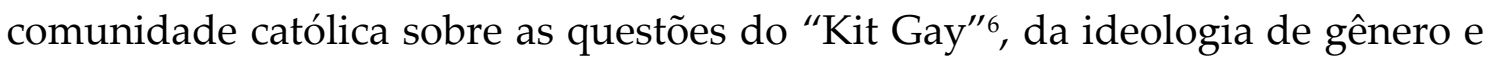
sobre a fundamentação ideológica dos partidos de esquerda. Argumentam que a CNBB foi cooptada por grupos comunistas que estão no comando da política brasileira, uma vez que os bispos que ocupam cargos diretivos nesse órgão católico são expoentes da teologia da libertação. Por outro lado, esse pensamento não é comungado com alguns setores do clero católico. Salientam

\footnotetext{
6 Rótulo arranjado pela Frente Parlamentar evangélica para brecar políticas de inclusão e educação para o combate à homofobia nas escolas de ensino médio.
} 
Religare, ISSN: 19826605, v.16, n.1, agosto de 2019, p.170-206.

tais setores que essa aproximação entre carismáticos e pentecostais reafirma posições fundamentalistas e conservadoras. Sob a ótica de grupos e movimentos progressistas cristãos, a articulação entre católicos e evangélicos sob a bandeira de "bons costumes e moral conservadora" não demonstrou uma nova forma de fazer política partidária, ao contrário, perpetuou a hegemonia dos interesses privativos e corporativos.

\section{As estratégias eleitorais dos carismáticos-católicos: combate dentro e combate fora}

A institucionalização do Ministério de Fé e Política (MFP), inicialmente denominado Secretaria Matias, deu-se nos anos 1990 (RESI, 2016). Contudo, desde o final da Ditadura Militar, muitos membros dos movimentos carismáticos, por iniciativas individuais, tentaram se eleger para os mais diversos cargos dos poderes executivo e legislativo (REIS, 2016). Essas candidaturas eram organizadas a partir das próprias estruturas criadas pelos candidatos, isto é, os candidatos, por iniciativas individuais, visitavam os grupos de oração para pedir voto, contavam com a ajuda de outros membros carismáticos para divulgar suas campanhas, criar estratégias de marketing político, arrecadar fundos financeiros, buscar apoio de outros segmentos católicos e do clero e manter relações com o partido pelo qual disputavam a eleição.

Prandi (1996), mostra que nos anos 1990 a região Sudeste conseguiu eleger dezenas de vereadores, alguns prefeitos e poucos deputados estaduais e federais ligados aos movimento carismático-católico. Cidades como Mococa (SP), Campinas (SP), São Carlos (SP), Sorocaba (SP), Cachoeira Paulista (SP), Jundiaí (SP), Araçatuba (SP), Limeira (SP), Santos (SP), Belo Horizonte (MG), Uberlândia (MG), Pará de Minas (MG), Sete Lagoas (MG), Unaí (MG) e Rio de Janeiro (RJ) conseguiram eleger e reeleger candidatos. 
Religare, ISSN: 19826605, v.16, n.1, agosto de 2019, p.170-206.

A partir dos anos 2000, o número de parlamentares eleitos aumentou no Brasil, devido a expansão do número de candidatos nos Estados do Nordeste, Sul, Norte e Centro-Oeste. Estes passaram a ter candidaturas apoiadas institucionalmente pela coordenação local da RCC ou pela própria iniciativa do militante carismático que se envolvia na política partidária (SILVEIRA 2008).

Realizando o perfil dos políticos carismáticos, Reis (2016) apontou que a maioria desses mandatários são pessoas com ensino superior completo, profissionais do serviço público, empresários, professores ou profissionais liberais. Partidos identificados ideologicamente como direita ou centro são os preferidos (DEM, PSDB, PMDB, PTB). Mas há também partidos que na coligação os ajudam a eleger de forma mais rápida, a exemplo do PHS. A grande maioria é de homens e a concentração das candidaturas continua na região Sudeste.

A RCC é, porém, um movimento dentro do catolicismo como um todo e possui segmentos e grupos internos com razoáveis diferenças. Por isso, para alavancar candidaturas são preferidos, como candidatos, líderes religiosos, cantores, apresentadores, em síntese, indivíduos que já possuem representatividade perante o público católico, por exemplo, o escritor e apresentador Gabriel Chalita e os músicos Flavinho e Eros Biodini (MANDUCA, 2015; REIS, 2016).

Com a institucionalização do MFP (Ministério Fé e Política), as coordenações diocesanas e estaduais intensificaram os apoios oficiais a determinadas candidaturas. As dioceses brasileiras passaram a ter disputas internas para obtenção do apoio dos grupos de oração e do clero simpatizante do movimento carismático (REIS, 2016).

No período preparatório para as eleições, os grupos de oração e os eventos promovidos pela RCC, para obter o apoio das lideranças e dos padres, viram palcos de disputa das pessoas que pretendem sair como candidatas. Não 
Religare, ISSN: 19826605, v.16, n.1, agosto de 2019, p.170-206.

são raros os momentos em que adeptos desse segmento católico são abordados para votarem no representante-candidato, solicitando o aconselhamento de estratégias políticas, são os espaços abertos dos eventos promovidos pelos carismáticos para o candidato falar de sua intenção. Mas disputas dentro do movimento levaram muitas dioceses as terem dissidências em função da escolha de um candidato em detrimento de outro, ou até mesmo a negação de apoio ao candidato.

A escolha de um único concorrente oficial deve-se ao fato de ser difícil eleger mais de um candidato apenas com o eleitorado carismático. Pode-se citar o exemplo da participação política da RCC da diocese de Uberlândia. No final dos anos 1990, a vereadora Fátima Paiva (que, antes de ser eleita, era coordenadora diocesana), após o final de seu mandato tentou se eleger como vice-prefeita da cidade de Uberlândia, no ano de 2000 (REIS 2016). Para obter votos e conseguir ser eleita, a postulante ao cargo articulou o apoio com outros movimentos, pastorais e padres. Outro exemplo é a candidatura de Walquir Amaral (PHS - MG).

Nas eleições de 2008 e 2012, ele tentou se eleger para o cargo de vereador. Nas reuniões com o staff que o acompanhava era consenso que, possivelmente, ele poderia conseguir centenas de votos entre os participantes dos grupos de oração, mas não eram suficientes para elegê-lo; então, iniciou diálogos com a Pastoral Familiar, Pastoral da Saúde, Movimento de Casais com Cristo (ECC) e com padres de outros segmentos católicos para conseguir seu intento (REIS, 2016).

Procópio (2012), ao estudar as candidaturas de Gabriel Chalita e do petista Odair José da Cunha, mostra que, para eles serem eleitos deputados federais, buscaram apoio em segmentos sociais não-católicos, ampliando seu público. Com isso, surge um dilema: se os candidatos ficam restritos a um discurso muito corporativo ou conservador, fica muito difícil dialogar com 
Religare, ISSN: 19826605, v.16, n.1, agosto de 2019, p.170-206.

grupos mais amplos. O dilema tende a duplicar o discurso dos candidatos carismáticos: uma fala interna, para os carismáticos, e outra, para os outros segmentos em geral. É possível, ainda, que os postulantes a cargos eletivos pela renovação carismática tendam a amenizar a radicalidade do discurso, sem perder alguns referenciais. Gabriel Chalita, em São Paulo, intensificou sua campanha entre os professores e agentes pedagógicos no âmbito escolar em função do seu vínculo com as escolas estaduais de São Paulo e por ter sido secretário de educação do governo de José Serra.

Odair Cunha, também ligado aos carismáticos, buscou apoio entre trabalhadores sindicalizados e outras profissões em função do seu envolvimento profissional (REIS, 2916). Por isso, em razão dos vários públicos que essas candidaturas buscam, os discursos são mais amplos e menos vinculados às diretrizes e ideias defendidas pela RCC. Projetos de leis, emendas parlamentares e outras formas de ajuda não são exclusivos para o movimento carismático.

A resistência ao apoio a mais de uma candidatura não é apenas em função da base eleitoral, mas está relacionada à própria trajetória política e ao envolvimento do postulado no apoio às atividades internas da RCC (REIS, 2016). Algumas candidaturas carismático-petistas, por exemplo, possuem dificuldades em serem aceitas pelos grupos de oração, novas comunidades e entre os padres, pela visão negativa que estes têm em relação ao partido dos trabalhadores (anticristãos). Ou, então, pela própria falta de habilidade política do candidato em tecer os apoios entre os atores carismáticos ou por querelas antigas com os membros do movimento em função de outros fatores.

O problema das dissidências internas em função de questões políticas é detectado pela direção nacional da RCC e exposto no documento oficial do Ministério de Fé e Política: 
Religare, ISSN: 19826605, v.16, n.1, agosto de 2019, p.170-206.

Apesar disso, pouco se avançou quanto à efetiva participação da RCC na política e muito se retrocedeu quando irmãos dedicados ao trabalho de evangelização do movimento se lançaram na política partidária e a RCC colheu como fruto amargo as brigas, as contendas e as divisões, que deram margem às decepções, feridas e até rancores entre os irmãos. Talvez pela lógica, presente na vala comum da atividade política e seus desdobramentos nada ortodoxos no debate eleitoral, que possivelmente não soubemos, ou não estávamos preparados para superar e enfrentar com a devida altivez. ${ }^{7}$

Percebe-se, nesse sentido, que a preocupação com os problemas internos da ação política dos carismáticos impede que suas pretensões políticopartidárias sejam concretizadas. Muitas dioceses optaram por não apoiar candidatos ou proibiram que seus membros se envolvessem na corrida partidária, dificultando que deputados estaduais, federais, pleiteantes a outros cargos (vereadores), tenham apoio nas dioceses. Por outro lado, essas barreiras aumentam a chance de não ter representantes nas cidades e nos estados implica projetos de lei não alinhados às diretrizes da Igreja Católica ou que não concretizam os interesses institucionais do movimento carismático.

Para que as pretensões político-partidárias fossem ampliadas com a eleição de novos membros, as disputas internas deveriam ter interferência na instância nacional da RCC com o objetivo de regular e normatizar a participação política dos seus membros. Assim:

Isto fez com que muitos participantes dos grupos de oração dessem as costas às questões políticas, dando margem a um período de descaso, misturado com um preconceito muito grande em relação à política e a todos aqueles que com ela se envolvesse. Sem perceber, estávamos fazendo exatamente o que o inimigo de Deus pretendia para não se fazer coisa alguma ${ }^{8}$ (ZAVARES, 2014, p. 7)

\footnotetext{
${ }^{7}$ Fragmento da palestra proferida por Sérgio Zavares, ex-coordenador do Ministério Nacional de Fé e Política da RCC, no Encontro Nacional de Formação da RCC-Brasil, ocorrido em 2014. Zavares Brasil. (REIS, 2016, p. 7).

${ }^{8}$ Fragmento da palestra proferida por Sérgio Zavares. (REIS, 2016, p. 7).
} 
Religare, ISSN: 19826605, v.16, n.1, agosto de 2019, p.170-206.

Com o intuito de oferecer as diretrizes do funcionamento desse ministério nas dioceses, o próprio documento oficial elaborado pelo Ministério de Fé e Política traz justificativas para a normatização e regulação da forma do envolvimento político-partidário dos carismáticos na política brasileira, explicando por que os cristãos devem se envolver na política.

\section{A realidade brasileira segundo os carismáticos e suas estratégias de ação}

Para os membros da RCC, em especial suas camadas dirigentes, a realidade política brasileira é desorganizada e sombria. A arena política é composta de inúmeros problemas causados pela corrupção e pela falta de competência para a gestão pública na implementação de políticas públicas que acabariam ou pelo menos diminuiriam os problemas sociais (SILVEIRA, 2008; REIS, 2016). Segundo os carismáticos, há problemas na condução da política econômica, aumento da exploração dos recursos do meio ambiente e urgência de uma reforma política (MACHADO, 2015).

Contudo, na visão desse grupo religioso, a resolução dos problemas político-econômicos e sociais do Brasil passaria pela moralidade cristã-católica, eleita como o fundamento das instituições públicas e da ação política dos parlamentares (REIS, 2016; SILVEIRA, 2018). Com a implantação do Estado Laico no Brasil em 1891 e o avanço da pluralidade religiosa e não religiosa, a Igreja Católica teve seu espaço e influência reconfigurados. A identidade nacional brasileira, que tinha como uma de suas marcas o fato de ser católica, é questionada e a pluralidade de outras identidades ascende ao espaço, porém, ainda concentrada no campo cristão. De toda forma, o espaço estatal republicano expurgou boa parte das bases teológicas, doutrinais e discursivas da hierarquia católica. 
Religare, ISSN: 19826605, v.16, n.1, agosto de 2019, p.170-206.

Nessa perspectiva, padres, bispos e intelectuais católicos perceberam que outros grupos sociais passaram a ocupar espaços e começaram disputas com o objetivo de, a partir de suas identidades, influenciarem decisões, sobretudo aquelas relativas à formulação de políticas públicas. A sociedade brasileira não possui mais uma identidade nacional unificada, cristalizada e baseada nos preceitos católicos como mostra a sua história. Com o processo de modernização das estruturas sociais, identidades antigas e novas intensificaram sua visibilidade, muitas delas baseadas em novas propostas políticas, novos movimentos sociais e partidos políticos, muitas vezes distantes das ideias defendidas pela Igreja Católica (GIUMBELLI, 2011).

Em muitos discursos cristãos, evangélicos e católicos, a secularização, laicização, os movimentos de esquerda, ateísmo, comunismo, socialismo, anarquismo, novos movimentos religiosos, dentre outros fenômenos, passam a ser inimigos e fontes do mal e mazelas sociais da sociedade brasileira (MAINWARING, 1989; MARIZ, 1998; LUNA, 2013, 2014 a, 2014 b; MACHADO, 2008, 2016). Nesse sentido, para reverter essa realidade plural, moderna, e para que os órgãos de governo sejam inspirados pelos princípios católicos, a RCC, pelo menos em suas lideranças, passou a justificar o seu envolvimento políticopartidário:

Colocar dessa maneira para o meio político para parecer ingênuo e até utópico, mas não será desproporcional ao desafio da cruz anunciada por Jesus Cristo quando falou a seus discípulos sobre a verdade da Salvação e do Reino de Deus. Então por que o medo de enfrentar os leões? Se nós já conhecemos o seu conselho: "Tomai, portanto, a armadura de Deus, para que possais resistir nos dias maus e manter-vos inabaláveis no cumprimento do vosso dever. Ficai alerta, a cintura, cingidos com a verdade, o corpo vestido com a couraça da justiça, e os pés calçados de prontidão para anunciar o Evangelho da Paz (Efésios 6, 13-15). ${ }^{9}$

\footnotetext{
${ }_{9}^{9}$ Fragmento da palestra proferida por Sérgio Zavares (REIS, 2016, p. 7).
} 
Religare, ISSN: 19826605, v.16, n.1, agosto de 2019, p.170-206.

No documento supracitado, a interpretação da realidade política brasileira é fundamentada em passagens bíblicas e em outros documentos da Igreja Católica (Pronunciamentos Papais, Encíclicas). Sugere, desse modo, que a RCC vê a política brasileira como um campo de guerra. Para poder vencer o conflito, seus membros precisariam se organizar e criar estratégias bélicas para combater seus inimigos e, assim, reconquistar o espaço perdido na política (SILVEIRA, 2008; REIS, 2016).

É muito comum, nos eventos da RCC, dizer que o político precisa ter as características que Jesus tinha em vida: combater a mentira e o mal, ser o guerreiro que morreu em nome da verdade única, defender a justiça e a paz, e sempre defender os valores acreditados pelos católicos (SILVEIRA, 2008; REIS, 2016). Todavia, essa interpretação deixa de lado o Sermão da Montanha: perdão absoluto e o oferecimento da outra face, quando te esbofeteiam.

Tais mensagens são complementadas pelo fato de que o clero católico que a Igreja Católica é a única instituição religiosa que contém a verdade universal, por ela ter sido fundada pelo próprio Jesus Cristo. Sendo assim, o político e todas as formas de participação política devem atuar para defender seus preceitos religiosos, o que se pode perceber neste trecho:

Isto faz toda a diferença, porque pode significar, principalmente para aqueles que advogam que Jesus foi um grande político, morrer para si mesmo e aceitar virar o cordeiro imolado no plano supremo do Criado em favor de muitos. Talvez, saindo como perdedor e aparentemente derrotado no campo político, mas sempre cumprindo a missão primeira que a Igreja chamou para ser testemunho vivo da fé em Jesus Cristo, portanto, não transgredindo com os valores morais e éticos - E isto sim, por si só, revela a missão mais importante de atuação na política ${ }^{10}$.

A citação acima revela o perfil de político e o entendimento da forma que os membros da RCC devem exercer a participação política. Os parlamentares

${ }^{10}$ Fragmento da palestra proferida por Sérgio Zavares (REIS, 2016, p. 8). 
Religare, ISSN: 19826605, v.16, n.1, agosto de 2019, p.170-206.

são porta-vozes de seus interesses nos diversos espaços da arena política brasileira. Toda forma de engajamento político tem por objetivo a moralização da vida pública brasileira. Para isso, ações proselitistas são necessárias e justificadas para derrotar os inimigos e a derrota acontecerá, no entendimento dos dirigentes desse grupo religioso, se seus parlamentares conseguirem ser eleitos para os mais diversos cargos e, também, evitar que políticos com propostas laicistas, secularistas, modernistas, liberais, sejam eleitos.

Objetivando reforçar o entendimento de que suas propostas políticas são as melhores e verdadeiras, os carismáticos constroem narrativas de desqualificação do outro em seus eventos, pois classificam e normatizam os grupos não cristãos como inimigos da fé, abortistas, com propostas desviantes da moralidade cristã, o que pode ser observado na Carta elaborada pela RCC da diocese de São Carlos, São Paulo (REIS, 2016):

\section{Carta de São Carlos}

Nós, líderes de movimentos universitários e de profissionais liberais católicos, reunidos na sede da Comunidade Católica Totus Mariae, na cidade de São Carlos, em São Paulo, Brasil, no dia 10 de dezembro de 2011, no evento "O cristão na vida pública" emitimos a seguinte carta pública. Diante de uma série de problemas que angustiam o homem e a sociedade contemporânea, dos quais é possível citar: o relativismo moral, a corrupção, a negação da verdade, o secularismo absolutista, que tentam negar o direito ao culto religioso e a participação dos fiéis na vida pública, e a alienação reinante nos meios de comunicação, declaramos:

1. A universidade, demais centros de formação superior, assim como o universo do trabalho, devem estar abertos para todas as ideias e discussões, inclusive as discussões fundamentadas em ideologias ateístas e seculares. No entanto, repudia-se o processo de exclusão que a religião, especialmente o Evangelho de Cristo, sofre dentro desses ambientes. Trata-se de ambientes plurais que, em tese, devem estar abertos a todas as ideias, inclusive ao Evangelho.

2. Rejeita-se o marxismo cultural que tenta, por meio da infiltração dentro das universidades, da mídia e de outros espaços públicos, construir uma sociedade sem Deus, sem fé e sem a presença da Igreja. A sociedade que essa versão do 
Religare, ISSN: 19826605, v.16, n.1, agosto de 2019, p.170-206.

marxismo quer construir é uma sociedade autoritária e fechada, onde não há espaço para a livre reflexão e muito menos para a expressão dos valores e sentimentos religiosos. Vale ressaltar que esses valores fundamentam as bases de qualquer modelo civilizatório.

3. Rejeitamos a cultura de morte. Uma cultura que se apresenta de diversas formas, como, por exemplo, o aborto, a união homossexual, a eutanásia, o suicídio assistido, a contracepção artificial, a destruição e o comércio de embriões humanos, a escravidão, a legalização das drogas etc. Infelizmente trata-se de uma cultura que, juntamente com o marxismo cultural, é muito difundida nos ambientes universitários e dos profissionais liberais. Uma sociedade justa, ética e alicerçada pelo Evangelho não pode ser orientada pela cultura de morte. Pelo contrário, tem que ser orientada pela cultura da vida e "vida em abundância" (Jo 10, 10), que promove o aperfeiçoamento de todas as dimensões da vida e da dignidade da pessoa humana.

4. Rejeitamos o secularismo absolutista e autoritário que, ao se apropriar de palavras, como por exemplo, "razão", "liberdade" e "revolução", que, muitas vezes, são utilizadas fora de seu real sentido, desejam banir e até mesmo proibir qualquer ato de manifestação de fé em espaço público. A fé é um direito fundamental do ser humano. Por isso, nenhuma ideologia, grupo empresarial, partido político ou organização social de qualquer natureza tem o direito de limitar sua livre expressão.

5. [...] conclamamos a todos os universitários, profissionais liberais e homens e mulheres de boa-fé a lutarem para que sejam garantidos os direitos religiosos, para que, em nome de um secularismo autoritário, a livre expressão da fé não seja, por diversos meios, proibida. Para que isso aconteça é preciso que os cristãos se façam presentes, cada vez mais, na vida pública. Essa presença deve ser materializada, por exemplo, na vida política partidária, dentro das mídias (rádio, jornal, blog, site etc), na vida cultural (cinema, teatro etc), dentro das universidades e demais centros de formação superior, e de qualquer outro espaço público que seja permitido, dentro dos limites da Lei, a livre expressão do pensamento. [...] Assinam essa carta: Marcos Gregório Borges - Coordenador da Missão Universitária de Guarulhos; Prof. Dr. Marcelo Melo Barroso Comunidade Católica Totus Mariae; Profa. Ms. Julianita Maria Scaranello Simões - Comunidade Católica Totus Mariae; Ms. Idalíria de Moraes Dias - Co-fundadora da Comunidade Católica Totus Mariae; Wilson José Dino dos Anjos - Fundador da Comunidade Católica Totus Mariae; Profa. Ms. Vanessa Burque Ricci - Comunidade Católica Totus Mariae; Michelle 
Religare, ISSN: 19826605, v.16, n.1, agosto de 2019, p.170-206.

Stephânia Pacheco Moraes - Comunidade Católica Totus Mariae; Daniela Inocêncio de Oliveira - Militante do Ministério Universidades Renovadas; Yanina Mara Rocha Nascimento Militante do Ministério Universidades Renovadas ;Marcelo Pastre - Apostolado Teologia do Corpo; Viviane G. C. Pastre Apostolado Teologia do Corpo; Luis Enrique Paulino Carmelo - Coordenador do grupo de Jovens Hesed (ministério Jovem RCC) e do Grupo Universitário Obra Nova; Thais Zaninetti Macedo - Coordenadora do Grupo de Jovens Hesed (ministério Jovem RCC); Luis Gustavo Paulino Carmelo - Coordenador do Grupo de Jovens Hesed (ministério Jovem RCC). Joice Basílio Machado - mestranda em Ciência da Computação pela USP.

A carta foi elaborada na cidade de São Carlos, conhecida nacionalmente como uma região de investimentos em pesquisas científicas, com muitas indústrias que desenvolvem tecnologias, e que também possui duas grandes universidades brasileiras - a Universidade Federal de São Carlos (UFSCar) e a Universidade de São Paulo (USP) (REIS, 2016). São priorizados pela RCC local os trabalhos realizados com universitários e profissionais com o objetivo de influenciar na formação de intelectuais e profissionais que possam sustentar teórica e metodologicamente as ideias defendidas pelos carismáticos, sobretudo, na política (REIS, 2016). Não é à toa que a Carta de São Carlos foi elaborada e assinada por militantes com grau de mestrado, doutorado, por professores universitários e por profissionais que já têm certo reconhecimento na sua área de atuação (MANDUCA, 2015).

Nota-se, nesse contexto, que a intenção dessa carta é recorrer a mestres, doutores e profissionais com ampla experiência em seus postos de trabalho para legitimar e dar status "acadêmico e erudito" às suas ideias. Assim, esse documento circulando em blogs, sites e redes sociais católicas e não católicas poderia atingir públicos não católicos que, portanto, pudessem aderir à sua visão de mundo (MANDUCA, 2015; REIS, 2016). Os argumentos usados na Carta de São Carlos mostram a visão dos dirigentes da RCC sobre os grupos 
Religare, ISSN: 19826605, v.16, n.1, agosto de 2019, p.170-206.

não cristãos, desqualificam sua ação política e os veem como inimigos que precisam ser derrotados (MANDUCA, 2015; REIS, 2016).

A Carta é um reflexo das relações de poder que ocorrem em diversos espaços da sociedade brasileira. Percebe-se que os conteúdos trazidos defendem a pluralidade do embate de ideias e retratam grupos religiosos que não são ouvidos nos setores da vida pública brasileira. Acrescentam que as identidades religiosas são discriminadas e que o "marxismo cultural" de forma autoritária impede que a universidade, a política e o mundo do trabalho assumam sua verdadeira missão de conduzir suas atividades a partir da ótica católica (REIS, 2016).

No entanto, constata-se uma contradição nesses argumentos, já que não aceitam a presença de grupos não religiosos ou dos que defendem as postulações laicistas e progressistas na vida pública nacional, isto é, não aceitam que o pensar diferente dos carismáticos tenham vez e voz nas instâncias decisórias da arena política brasileira (SILVEIRA, 2015). Pode-se exemplificar tal posicionamento quando esse grupo defende que a ciência e a ação profissional devem ser submissas aos padrões católicos, e assim, desenvolver conhecimentos e tecnologias que sustentem uma postura contrária ao aborto, casamento gay, eutanásia, prostituição, dentre outras questões (argumentos que são muito comuns nos políticos carismáticos em seus pronunciamentos nas instâncias públicas brasileiras) (SILVEIRA, 2015; REIS, 2016).

A Carta de São Carlos faz menção à defesa da liberdade de expressão, autonomia do uso da razão e acusa um suposto secularismo autoritário das instituições públicas brasileiras, uma vez que os grupos religiosos estão excluídos ou marginalizado dos debates públicos. Se são um espaço plural de discussões e debates, os carismáticos reivindicam presença e desejo de ter voz e serem ouvidos (MANDUCA, 2015; REIS, 2016). No entanto, o que os católicocarismáticos advogam é uma resistência contra a laicização e a secularização 
Religare, ISSN: 19826605, v.16, n.1, agosto de 2019, p.170-206. que vêm ocorrendo no Brasil (SILVEIRA; 2015). Em síntese, existe o desejo por parte dos carismáticos de que todo o funcionamento da sociedade brasileira volte a ser fundamentado nos valores católicos, o que justifica e motiva a sua participação política, principalmente, pela via partidária (MANDUCA, 2015; REIS, 2016). Essa maneira dos carismáticos pensarem e agirem politicamente parece autoritária, embutindo uma constante negação do outro (e, assim, paradoxalmente, um desprezo pela pluralidade de pensamento), uma vez que a forma única, correta e aceita são apenas aquelas ideias por eles defendidas.

\section{O Ministério de Fé e Politica: as tropas e armas dos carismáticos- católicos}

O Ministério de Fé e Política, ligado ao movimento da Renovação Carismática Católica, se apresenta como uma instância que deseja regular e normatizar todas as ações desse segmento religioso no tocante às questões políticas (MANDUCA, 2015; REIS, 2016). Porém, detecta-se que há desinteresse dos próprios membros em assumir frentes de trabalho propostas pelas diretrizes elaboradas pelos coordenadores nacionais (REIS, 2016). As razões da baixa participação política dos carismáticos devem-se ao fato de eles terem uma visão negativa da política brasileira em função dos escândalos de corrupção, do histórico de péssimos gestores públicos frente aos mais diversos cargos da administração pública e do pouco conhecimento do funcionamento das instituições públicas no Brasil. Sendo assim, o MFP iniciou uma série de ações que têm por objetivo sensibilizar as pessoas para a necessidade de aderirem às iniciativas desse ministério (MANDUCA, 2015; REIS, 2016).

Uma das iniciativas é a publicação quadrienal da Cartilha de Fé e Política, um manual para o fiel católico carismático divulgado nos anos de eleições majoritárias. A organização da cartilha se dá inicialmente desmistificando os males da política, instigando a participação do fiel na vida 
Religare, ISSN: 19826605, v.16, n.1, agosto de 2019, p.170-206.

pública. Segue-se um tópico explanando o perfil do candidato e do eleitor carismático (MANDUCA, 2015; REIS, 2016). O primeiro deve ser honesto, transparente e comprometido com a igreja e com a fé católicas. O segundo deve ser uma pessoa de oração que deve se deixar guiar pelo Espirito Santo. Por fim, a cartilha dá diretrizes para o acompanhamento dos cristãos eleitos (REIS, 2016).

A Cartilha de Fé e Política colabora diretamente com o direcionamento político da RCC. O moimento não apoia oficialmente nenhum candidato, porém, se utiliza de estratégias paralelas para lançar seus representantes. Ao indicar o perfil do candidato que deve ser votado o movimento se utiliza das mídias católicas para a divulgação de perfis similares ao divulgado, como na eleição do Deputado Evanadro Gussi, em 2014 (MANDUCA, 2015).

Uma iniciativa importante é obter espaço em eventos de massa para falar do significado da política para esse grupo religioso e os motivos pelos quais as pessoas devem envolver-se nos trabalhos do Ministério de Fé e Política (MANDUCA, 2015; REIS, 2016). Pensando nisso, em sua programação, o Encontro Nacional de Formação de 2014 inseriu pregações direcionadas aos temas relacionados à política (MANDUCA, 2015; REIS, 2016). Supomos que a escolha desse evento se deve a sua capacidade de atração de pessoas (milhares) de todos os Estados do Brasil. Na oportunidade, discursou-se sobre política em um dos principais eventos anuais, que ocorre na cidade de Aparecida do Norte, interior de São Paulo.

Apresenta-se aqui um trecho da palestra proferida, nesse evento, pelo então coordenador nacional do MFP:

Nós vemos o quanto de certa forma a nação brasileira tem colocado peso sobre essa questão, dizendo que a política é o mal de todos os nossos problemas, é o causador de todas as nossas mazelas; nós gostaríamos de dizer no fundo, no fundo a uma celebre frase que diz que "Cada povo tem o governo que merece", é um pouco dura de se dizer, mas ela é necessária pra 
Religare, ISSN: 19826605, v.16, n.1, agosto de 2019, p.170-206.

que nós entendamos a dimensão de estarmos envolvidos com a política para que ela possa ser agente de transformação, então se a política que nós vemos não é aquela que nós gostaríamos é necessário que nós comecemos a dar passos incisivos na transformação das coisas como estão, e a partir do amor que é plantado em cada um de nós, fazer as coisas naquilo que DEUS me pede... pode ser que ele te peça para ser um candidato, mas possa ser que ele te peça pra ser um bom servidor, pode ser que ele te peça pra ser um grande evangelizador pra tantos servidores, pode ser que ele te peça pra orar pela nação brasileira acusando a política de ser algo ruim, a parte daquilo que é também próprio do reflexo de nós mesmos não vai transformar a sociedade somente conseguiremos transformar a sociedade se nós sentirmos que a política é parte de nós também e aí colocando o princípio da nossa discussão que narrava "O cristão como agente de unidade na sociedade"11.

Ao longo da palestra, o ex-coordenador nacional do MFP justificou a necessidade da atuação dos membros da RCC nas questões políticas para melhorar a atual realidade caótica das instâncias políticas brasileiras (MANDUCA, 2015; REIS, 2016). Tal apelo deve-se ao fato de que, nesse discurso, sem o envolvimento dos carismáticos, dificilmente se conseguirá eleger seus representantes e criar uma consciência na defesa dos valores defendidos pelos católicos. As "tropas" carismáticas devem militar pelas causas gerais do catolicismo e interesses particulares da RCC para que os privilégios conquistados, historicamente, pela Igreja Católica não sejam ameaçados.

É comum verificar nas dioceses, o entendimento de que o MFP atua em âmbito estadual e regional apenas no período das eleições na tentativa de eleger seus representantes (MANDUCA, 2015; REIS, 2016). Por mais que as diretrizes apontem para uma ampliação no entendimento de como se deve envolver na política, apenas a questão partidária tem sido privilegiada em função dos interesses pessoais de seus membros em fazer carreira na política. Logo, não são raras as vezes que membros são eleitos e não voltam mais aos grupos de oração ou desaparecem das atividades do movimento, caracterizando oportunismo do

\footnotetext{
${ }^{11}$ Fragmento da palestra proferida por Sérgio Zavares (REIS, 2016, p. 8).
} 
Religare, ISSN: 19826605, v.16, n.1, agosto de 2019, p.170-206.

candidato ao aproveitar a estrutura midiática, usar os membros como cabos eleitorais, e na própria atuação parlamentar não defender os interesses de sua base eleitoral.

Outra razão é a falta de interesses das lideranças locais em desenvolver atividades organizadas pelo MFP. A tendência é que nas dioceses enfatizem-se as atividades de formação de grupos de oração, eventos de cura e libertação ou eventos de massa. Na tentativa de realizar uma mudança dessa mentalidade e uma intervenção nacional nas atividades regionais desse ministério, Zavares salienta:

[...] nós colocamos ministério de fé e política, portanto, política refere-se ao político e fala só da eleição, não é isso, a renovação é chamada por DEUS a estar se envolvendo com questões que ultrapassam inclusive o político, a máquina do Estado brasileiro não é tocada só por agentes eleitos, a máquina do Estado brasileiro é tocada também por servidores públicos concursados, servidores públicos empossados com cargo de confiança; eu mesmo sou um professor federal, fiz um concurso em 1992 e desde então sou professor de uma instituição federal de ensino, não estou sujeito as leis eleitorais, a cada 4 anos eu não preciso fazer o concurso de novo, né? Estarei lá até a minha aposentadoria se assim DEUS quiser, mas a máquina do Estado brasileiro, portanto, é tocada também por agentes políticos, por servidores e aí essa dimensão é que eu resgato aqui como importante de compreensão pra todos nós pessoal, nós temos uma responsabilidade com toda essa nação brasileira ${ }^{12}$.

Percebendo que nem todos os integrantes do movimento carismático têm habilidade para o envolvimento na política partidária e que nem a RCC possui estrutura para ajudar na eleição de todos os interessados, com o objetivo de ampliação de suas atividades, o MFP atua dentro de outros segmentos da sociedade, de acordo com as diretrizes:

Por isso, tal pilar de ação vem ganhando expressão através de eventos, que vão desde encontros para Juízes e Promotores de

${ }^{12}$ Fragmento da palestra proferida por Sérgio Zavares (REIS, 2016, p. 8). 
Religare, ISSN: 19826605, v.16, n.1, agosto de 2019, p.170-206.

Justiça até seminários para Policiais e Fóruns para Professores. Este pilar de ação representa uma resposta muito importante para a responsabilidade que a RCC tem com o anúncio da boa nova, especialmente para com aqueles que precisam de uma oportunidade para ouvir o chamado de Deus e abrir o coração para Jesus Cristo ${ }^{13}$

Para conseguir atingir outros públicos, o MFP busca parceria com os demais ministérios da RCC, ou, nas palavras dos carismáticos, a "ministerialidade orgânica":

[...] proposta de que ao invés de uma democracia participativa nós começássemos a nos preocuparmos com um modelo de democracia, é perdão! Ao invés de um modelo de democracia representativa, que é o modelo atual, começássemos a desenvolver a preocupação para um projeto de democracia participativa; O que significa isso? Não sei, talvez através de mídias, como a internet, vai perguntar a cada etapa soluções mais pontuais. O fato é que hoje nós já temos ferramentas que nos permitiriam a começar a refletir mais incisivamente na participação popular e hoje a renovação está sendo chamada a uma participação na política, volto a insistir, política não é um assunto somente do ministério de fé e política é de todos nós, por isso nós estamos conclamando acima de tudo um trabalho de Ministerialidade Orgânica, uma palavra já antiga que foi proposta há muito tempo atrás e que fala que na verdade o meu assunto pertence a você ministério de música, o seu assunto pertence a ele ali do ministério das famílias e as famílias pertencem a todos nós, ou seja, todos nós temos famílias, então todos os assuntos pertencem a todos e assim o fazendo vocês todos aqui hoje são do ministério de fé e política, Parabéns! Não seremos então especialistas, a divisão da renovação em ministérios não se configura em divisão de times de futebol, eu não vou escolher um pra começar a torcer por aquele time, é simplesmente uma organização pra que fique mais fácil a atuação pastoral, a atuação espiritual que a renovação tem a partir do batismo no espírito santo, é muito importante que a gente entenda que faz parte da minha responsabilidade o ministério da criança, faz parte da minha responsabilidade também o ministério de música, e confesso o meu pecado eu devo até me esforçar mais pra fazer ponte com outros ministérios como de música, quem sabe eu tenha até algum

${ }^{13}$ Fragmento da palestra proferida por Sérgio Zavares (REIS, 2016, p. 8). 
Religare, ISSN: 19826605, v.16, n.1, agosto de 2019, p.170-206.

dom, mas a gente tem feito um esforço nesse sentido e hoje o ministério de fé e política tem feito muito, tem andado muito em sintonia com o ministério de promoção humana, mas também com o ministério de formação; a ponto de que as apostilas que estão sendo revistas, nós participaremos incisivamente na revisão daquela apostila de doutrina social da igreja que era a última e que de certa forma a apostila 8 acabava ficando por último mesmo, em todos os sentidos ${ }^{14}$.

A partir de 2014, iniciaram diversas atividades promovidas conjuntamente com outros ministérios, novas comunidades, padres e outras expressões carismáticas com o intuito de converter as pessoas à sua proposta de identidade religiosa, e assim, dentro de seus segmentos profissionais e políticos, influenciar nas decisões (MANDUCA, 2015; REIS, 2016; SILVEIRA, 2015). Como exemplo, o Ministério Universidades Renovadas, que organiza congressos e debates nas universidades posicionando-se contra o aborto, cotas para negros e projetos de extensão voltados para a questão da homossexualidade ou questões que envolvam a "ideologia de gênero" (PROCÓPIO 2012; MANDUCA, 2015; REIS, 2016; SILVEIRA, 2015).

Além disso, nas eleições para os centros acadêmicos universitários, não foram raras as vezes que as chapas formadas por universitários defendessem o direito de os grupos religiosos realizarem atividades, por exemplo, contra festas e favoráveis a criação de grupos com a finalidade de divulgar a doutrina católica. O Ministério dos Profissionais atua para ajudar os políticos a elaborarem propostas de projetos de leis para atender às demandas dos seus segmentos (PROCÓPIO, 2012; MANDUCA, 2015; REIS, 2016). O Ministério de Formação organiza retiros em finais de semana e palestras sobre temas relacionados à doutrina social da Igreja, história da Igreja Católica e sobre noções básicas de filosofia e política para formar uma opinião sobre a realidade

${ }^{14}$ Fragmento da palestra proferida por Sérgio Zavares (REIS, 2016, p. 8). 
Religare, ISSN: 19826605, v.16, n.1, agosto de 2019, p.170-206.

nacional e todos conhecerem bem as ideias defendidas pelos católicos (MANDUCA, 2015; REIS, 2016).

O Ministério de Promoção Humana tornou-se importante devido a sua aproximação com os projetos sociais já desenvolvidos pela RCC, assim como o setor de comunicação é importante pela cobertura dos eventos. Outros ministérios ajudam na parte musical, no cuidado das crianças, e na formação de sexualidade para os jovens e para os casais, dentre outras parcerias. (MANDUCA, 2015; REIS, 2016).

Contudo, a atividade que mais cresceu foi a dos grupos de oração específicos por segmentos. Surgiram grupos de oração para policiais, bombeiros, professores, domésticas e servidores públicos federais.

Percebe-se a atuação do MFP no estado do Rio de Janeiro a partir do trabalho com outros públicos:

\begin{abstract}
É... a primeira coisa que, que nós fizemos, né? Foi trabalhar uma formação, né? Tanto é que não tinha nada escrito sobre o Ministério e nós nos reunirmos em equipe nacional, né?, A partir do momento em que você é coordenador de Estado, você faz parte de uma equipe nacional e dentro dessa coordenação nacional nós escrevemos um projeto que servia para toda renovação carismática, então o primeiro projeto foi escrever esse livro, né? que é Fé e Política da Renovação Carismática e no estado do Rio nós fizemos um trabalho de evangelização com policiais militares, né?, toda a área militar na realidade, bombeiro, pessoas do exército, da marinha, da aeronáutica e... é principalmente com o policiais militares devido a tudo que estava acontecendo no Rio de Janeiro é... Como muitos policiais estão morrendo, nós trabalhamos a evangelização das famílias dos policiais militares ${ }^{15}$.
\end{abstract}

Outras atividades em nível nacional, estadual e municipal têm sido promovidas e organizadas pelo próprio MFP envolvendo a temática Fé e Política. Todas essas iniciativas têm sido coordenadas e seguidas por diretrizes criadas pelo Ministério de Fé e Política da RCC com o objetivo de estimular ${ }^{15}$ Fragmento da palestra proferida por Sérgio Zavares (REIS, 2016, p. 8). 
Religare, ISSN: 19826605, v.16, n.1, agosto de 2019, p.170-206.

outras formas de participação política dos seus membros. Desde a sua fundação, uma das estratégias diz respeito à formação dos seus membros com o objetivo de promover escolas de fé e política em todas as regiões no Brasil visando a atrair as pessoas para os projetos políticos desenvolvidos em todos os níveis pelas instâncias burocráticas da RCC. (MANDUCA, 2015; REIS, 2016).

Os conteúdos ministrados giram em torno da Doutrina Social da Igreja, História da Igreja, História Política do Brasil, Cidadania, Democracia, dentre outros temas, conforme mostra o ex-coordenador nacional do MFP:

[...] A primeira dimensão chamo de formação, que tem por objetivo propagar a Doutrina Social da Igreja entre os membros dos grupos de oração. Para isto é preciso que sejam formadas escolas, ou etapas dentro da escola geral (Paulo Apóstolo), com linguagem apropriada ao nosso povo e com ensinamentos simples que possam orientar o povo sobre cidadania, solidariedade, subsidiariedade, e outros pontos fundamentais da doutrina e do Evangelho. A Escola deverá ter uma estrutura nacional e outra local, bem como materiais para instrução dentro dos próprios grupos de oração ${ }^{16}$.

Estrategicamente, o MFP desenvolve metodologias pedagógicas para atingir pessoas de todos os níveis educacionais (MANDUCA, 2015; REIS, 2016). Dessa forma, garante que todos tenham acesso ao material e às aulas, além de poderem envolver-se politicamente, conforme as diretrizes. Os documentos oficiais do MFP reforçam a ideia de que pessoas são escolhidas para irem aos grupos de oração, cenáculos, festivais musicais, missas de cura e outros eventos para falarem de "política", isto é, aproveitarem os espaços dos eventos de massa para promoverem a disseminação de suas ideias políticas. (MANDUCA, 2015; REIS, 2016).

Dessa maneira, portanto, é comum nos eventos, sobretudo aqueles transmitidos pelo rádio, pela televisão ou internet, mensagens de orientação em quem não votar, critérios de escolha de voto, pedidos de abaixo-assinado contra ${ }^{16}$ Disponível em: <http://www.rccbrasil.org.br/artigo.php?artigo=99>. Acesso em: 09 nov. 2013. 
Religare, ISSN: 19826605, v.16, n.1, agosto de 2019, p.170-206.

algum projeto de lei ou, ainda, a propagação de aspectos dogmáticos mostrando as razões a favor ou contra o tema. Nas palavras do ex-coordenador do MFP:

[...] A segunda dimensão eu chamo de agentes mobilizadores, e trata de formar indivíduos cheios do Espírito e do ardor social que, através das estruturas dos grupos de oração e com o apoio das mídias católicas, possam discernir os pontos fundamentais de luta e mobilização, para que o bem comum seja garantido pelas leis e cumprido pelos organismos executores. Através de pregações e organização dentro dos grupos de oração, promover o desenvolvimento de ações para despertar e motivar a população a obter as transformações necessárias e os direitos adquiridos, inclusive das minorias. [...] Os mobilizadores deverão, pela pregação inspirada, abrir os corações para as questões sociais e políticas, motivando e acendendo o desejo ardente de servir a Jesus, se necessário for pelo martírio ${ }^{17}$.

Uma frente de batalha importante é o convencimento de pessoas que ocupam cargos no Estado, tentando convencê-las a integrarem a política partidária ou desenvolverem projetos sociais. A partir das Escolas de Fé e Política, indivíduos seriam escolhidos para envolverem-se nessa vertente de trabalho. (MANDUCA, 2015; REIS, 2016). Advogados, administradores, cientistas políticos, marqueteiros, empresários, filósofos, professores comporiam comissões para dar estrutura financeira, jurídica, empresarial e educacional para as pessoas que sejam ligadas a cargos públicos, não obrigatoriamente parlamentares (MANDUCA, 2015; REIS, 2016). Percebe-se isso quando o ex-coordenador nacional do MFP retrata:

[...] Por fim, a terceira dimensão, ou perna deste tripé, que chamo "um Brasil na cultura de Pentecostes", que é organizar as forças políticas e pensadores da nossa sociedade para, a partir do batismo no Espírito Santo, apontarem rumos para o Brasil, mobilizando profissionais novos, profissionais do Reino, em parceria com o Ministério das Universidades Renovadas e

${ }^{17}$ Fragmento da Palestra proferida por Sérgio Zavares (REIS, 2016, p. 7). 
Religare, ISSN: 19826605, v.16, n.1, agosto de 2019, p.170-206.

Ministério de Promoção Humana, definindo onde queremos que o Brasil chegue ${ }^{18}$.

O público prioritário é constituído por pessoas do meio universitário e que tenham experiências com projetos sociais, o que possibilita um conhecimento da realidade para a elaboração de projetos de lei, pois a pessoa com nível educacional elevado, teoricamente, tem conhecimentos para lidar com questões do mundo político ou da área do projeto social desenvolvido. Com isso, os encontros foram promovidos por categorias para abarcar as especificidades desse público-alvo (MANDUCA, 2015; REIS, 2016).

O grupo que vem ganhando destaque nos eventos é o dos juízes, promotores, advogados e pessoas ligadas ao meio jurídico. Anualmente, é feito um encontro para esse grupo profissional no intuito de que suas decisões sejam fundamentadas a partir dos dogmas católicos, ou seja, no Brasil muitos problemas nacionais são resolvidos e decididos a partir dos votos dos juízes que compõem os órgãos competentes (REIS, 2016). Além disso, os advogados podem prestar assessoria jurídica para eventuais problemas na Justiça envolvendo expressões carismáticas nacionais, estaduais e municipais ou para conseguir algum benefício do setor público. (MANDUCA, 2015; REIS, 2016).

Na Figura 10, apresenta-se o cartaz do Encontro Nacional Católico para Magistrados e Membros do Ministério Público realizado em 2012 no Estado de São Paulo.

${ }^{18}$ Fragmento da Palestra proferida por Sérgio Zavares (REIS, 2016, p. 8). 
Religare, ISSN: 19826605, v.16, n.1, agosto de 2019, p.170-206.

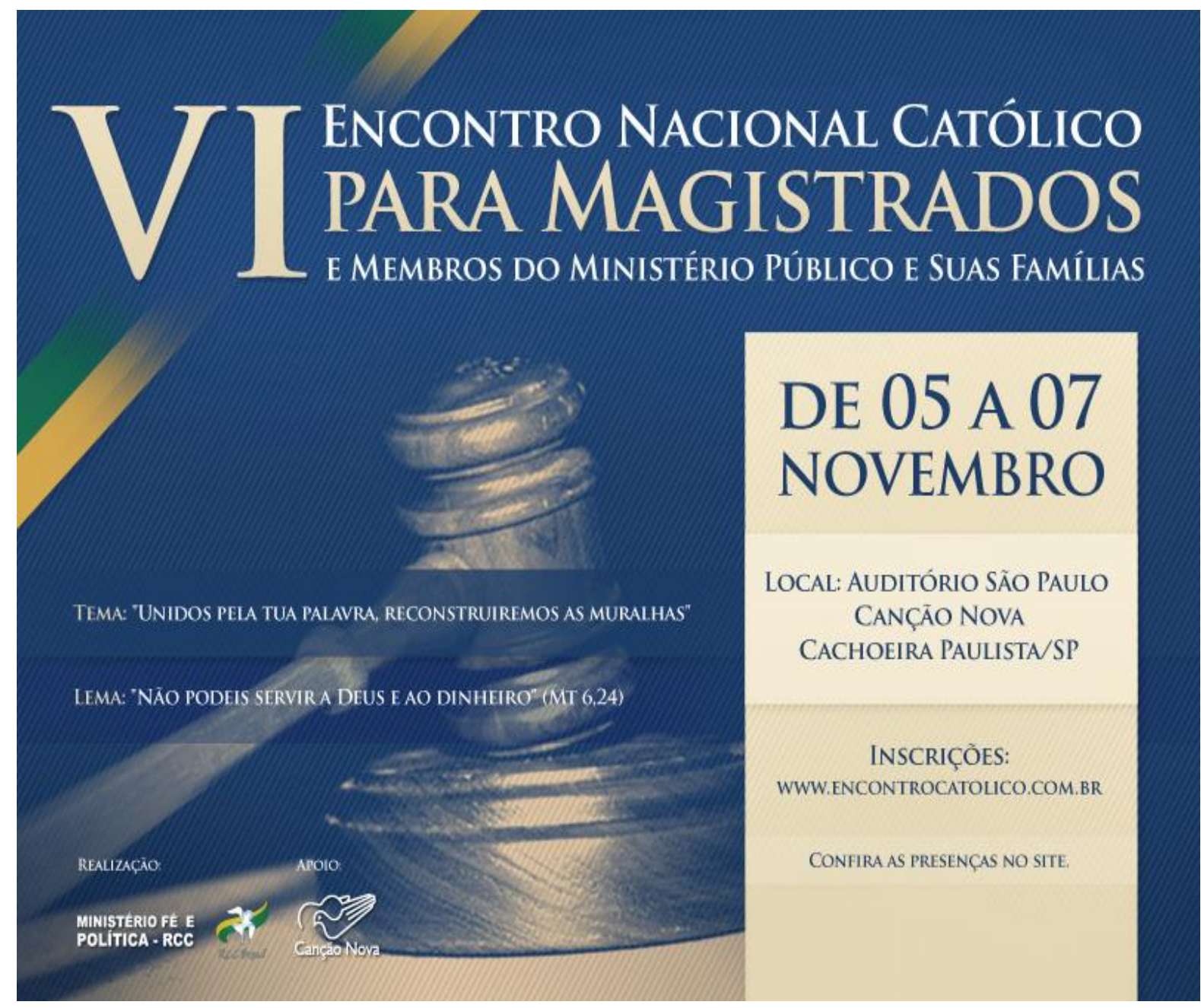

Figura 1 - Cartaz do Encontro Nacional Católico para Magistrados e Membros do Ministério Público

Fonte: Site nacional da RCC BR

Observando a Figura 1, percebe-se que tanto o tema como o lema do evento dizem respeito à necessidade de reconstrução do Brasil a partir da ótica cristã. O País está inserido em corrupção, injustiças, problemas sociais e econômicos e, para reverter esta realidade, faz-se necessária a atuação dos magistrados e das pessoas ligadas ao serviço público (REIS, 2016).

Com esse intuito, na programação do evento, são trabalhados temas como: as relações entre Igreja e Estado; a realidade da Igreja Católica no Brasil; a inserção da RCC na vida política; a importância do meio jurídico para o catolicismo, para a saúde pública, para educação e para o funcionamento da máquina estatal, dentre outros. Observe-se este cartaz: 
Religare, ISSN: 19826605, v.16, n.1, agosto de 2019, p.170-206.

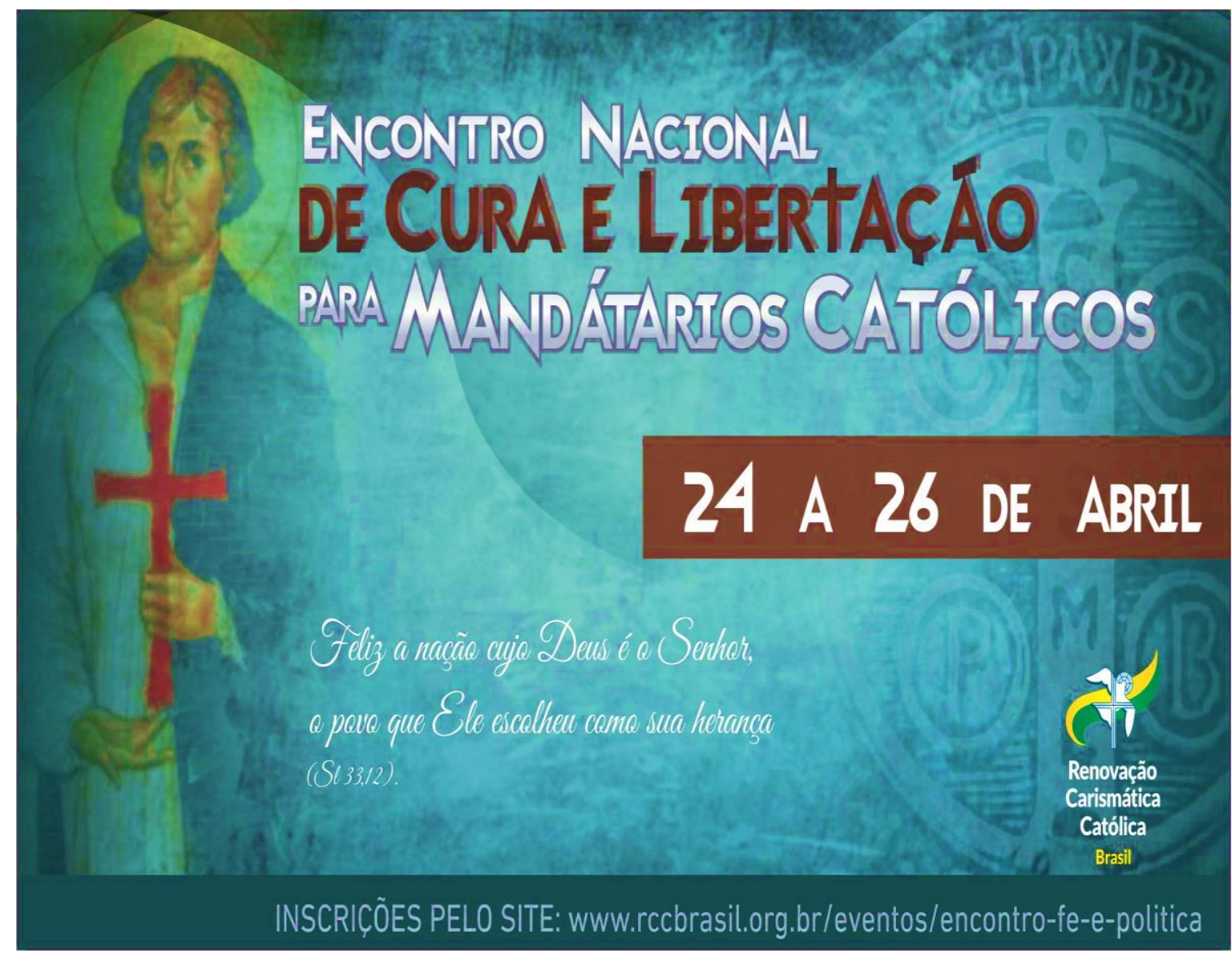

Figura 2 - Cartaz do Encontro Nacional de Cura e Libertação para Mandatários Católicos

Fonte: Site nacional da RCC BR

Por ser tratar de um encontro de "cura" e "libertação", a mensagem de combate da fé é utilizada com nova roupagem (REIS, 2016). Para que os parlamentares possam cumprir sua missão de lutarem pelos valores da fé católica, eles precisam ser curados e libertos de quaisquer obstáculos que os impeçam de cumprir essa meta, portanto, o mandatário precisa ser "tratado" espiritualmente. (MANDUCA, 2015; REIS, 2016). A passagem bíblica “Feliz a nação cujo Deus é o Senhor, o povo que ele escolheu como sua herança" reforça a ideia de que o Brasil é um País que deve ser governado - e as pessoas que moram nele - sob a ótica cristã. (MANDUCA, 2015; REIS, 2016).

O cartaz da Figura 2, traz a imagem de um homem segurando uma cruz, símbolo do catolicismo que representa o caminho para a salvação da 
Religare, ISSN: 19826605, v.16, n.1, agosto de 2019, p.170-206.

humanidade, que se materializa por meio da morte de Jesus (REIS, 2016). Nesse sentido, o político católico carismático precisa fazer "sacrifícios" para salvar o mundo. Assim, seus projetos de lei, obras sociais, discursos políticos e articulações políticas precisam refletir esse significado. A cruz significa obediência e fidelidade, por isso o mandatário não pode atuar de acordo com seus interesses e visão de mundo, mas sim de acordo com a visão da comunidade e os direcionamentos do clero (MANDUCA, 2015; REIS, 2016). Há, ainda, traz a imagem de São Thomas More. Tal "santo" é visto pela Igreja Católica como exemplo de político, que viveu durante o século XVI, na Inglaterra, e foi condenado à morte por não reconhecer, nesse país, a autoridade de Henrique VIII sobre a Igreja Católica. Sendo assim, a ideia é a de que os políticos ligados à RCC independentemente das situações, mantenham-se fiéis aos valores cristãos (REIS, 2011).

\section{A luta contra o aborto como bandeira católica: o front de batalha}

Das questões de maior destaque apresentadas por eleitos da Renovação Carismática Católica o aborto a interrupção voluntária da gravidez merece destaque. Além do contexto latino-americano, em que a liberalização do aborto tem sido debatida em países como Brasil e Argentina e a recente liberalização no Uruguai, em 2013, a criminalização do aborto é uma bandeira historicamente católica. (SANTIN, 2000; MIGUEL, 2012, 2016; RIBEIRO, 2012; MANDUCA, 2015; REIS, 2016; MIGUEL, 2016).

O aborto induzido, quando o fim da gestação é antecipado através de medicamentos ou procedimentos cirúrgicos, é considerado crime passivo de punição pelo Artigo 129 do Código Penal desde 1984. A pena não se configura nos casos de não haver outro meio de salvar a criança ou quando a gravidez resulta de estupro (Artigo. 128). (MIGUEL, 2016). Desde 2012 ele é permitido também se o feto for diagnosticado como anencéfalo (MIGUEL, 2016). A luta 
Religare, ISSN: 19826605, v.16, n.1, agosto de 2019, p.170-206.

dos movimentos pró-vida é pela criminalização do aborto induzido nesses casos e pelo impedimento de que novas exceções sejam inseridas na lei. Contrariando os preceitos de "Defesa da vida" o aborto é totalmente condenado pelo catolicismo, sobretudo o carismático, enquanto seus estudos referentes à AD e à IURD apontaram, apesar de veemente condenação, uma maior flexibilização por parte das lideranças (MACHADO, 2015).

Segundo Rosado-Nunes (2000; 2002) a interrupção voluntária da gravidez se tornou pauta política dos evangélicos pentecostais após o envolvimento de parlamentares evangélicos em escândalos de corrupção ${ }^{19}$. Em consequência, o discurso de uma idoneidade política baseada em preceitos religiosos se enfraqueceu. Atualmente, os líderes da Frente Parlamentar Mista em Defesa da Vida são os evangélicos Ronaldo Fonseca e Magno Malta.

Dessa forma, são comuns alianças entre pentecostais evangélicos e católicos, num cenário em que a disputa por espaço dentro do Mercado Religioso dá lugar a um embate entre religião e secularismo. Essas se manifestaram desde a aprovação do $3^{\text {o }}$ Plano Nacional de Direitos Humanos (PNDH-3) até a recente Proposta de Emenda Constitucional 181 (PEC 181).

O primeiro caso foi fundamental para a campanha à presidência de Dilma Roussef em 2010. Apontada como favorável ao aborto, devido a declarações dadas em entrevista ao jornal Folha de São Paulo, foi necessária uma reformulação da imagem da candidata para conseguir o apoio religioso. Como demonstram Maria das Dores dos Campos Machado (2012) e Naara Luna (2014 a; 2014 b), a reformulação do plano promulgado por seu antecessor, Luiz Inácio Lula da Silva, em que se retirou um parágrafo que dava aberto apoio à descriminalização da prática abortiva e abria a possibilidade para a interrupção voluntária da gravidez. A PEC-181 é talvez umas das mais elucidativas em

${ }^{19}$ Como destaque o envolvimento de Carlos Alberto Rodrigues Pinto, o iurdiano conhecido como bispo Rodrigues, no caso da "Máfia das Sanguessugas" em 2006. O escândalo teve grande número de evangélicos envolvidos e culminou em uma breve diminuição da representação evangélica no Congresso Nacional (SOUZA, 2013) 
Religare, ISSN: 19826605, v.16, n.1, agosto de 2019, p.170-206.

relação as alianças religiosas em prol de questões morais. Advinda de um a proposta do Senado Federal que buscava aumentar a licença maternidade da mãe de bebê prematuro, ao chegar à Câmara dos Deputados foi instalada uma Comissão Especial para debate-la (REIS, 2016).

A composição política opositora foi articulada pelo deputado membro da Assembleia de Deus, João Campos, que convidou o carismático católico Evandro Gussi, como presidente, e como vices o Leonardo Quintão da Igreja Presbiteriana, Jorge Tadeu Mudalen da Igreja Internacional da Graça, Geovania de Sá da Assembleia de Deus e o também membro da RCC Flavinho (REIS, 2016; MIGUEL, 2016). A comissão tinha como proposta inserir no texto original da PEC um artigo que considerava como vida, para o Estado brasileiro, a partir da concepção, algo que torna crime qualquer prática abortiva voluntária, mesmo as já previstas por lei. Em uma comissão que possui $75 \%$ de seus membros declaradamente religiosos, e $88 \%$ do sexo masculino, o texto foi aprovado por 18 votos à um, e segue agora para debate na Câmara dos Deputados. (MIGUEL, 2016).

Como se pode ver, as tropas carismáticas uniram-se a tropas evangélicas em uma grande tentativa de atrasar a tramitação de legislação laica e secularista, em especial à relativa ao aborto, por um lado, e, por outro, avançam em pautas conservadoras e corporativistas.

\section{Considerações Finais}

A Renovação Carismática Católica é hoje um movimento bastante expressivo dentro do catolicismo, sobretudo o latino-americano. O movimento ganhou seu protagonismo nos anos 1980, cresceu em uma perspectiva de introspecção religiosa, uso de carismas extraordinários e experiências místicas, entretanto, durante os anos 2000, sua direção geral o reorganizou e encaminhou para pautas político-conservadoras. Um dos motivos possíveis foi a 
Religare, ISSN: 19826605, v.16, n.1, agosto de 2019, p.170-206.

concorrência com os evangélicos pentecostais que vinham ganhando protagonismo na política partidária, que até então era monopolizada por católicos. A RCC sentiu necessidade de colocar em marcha uma estratégica política e tem tentado eleger representantes políticos. Para isso foi necessária uma movimentação similar à de seus adversários religiosos, a saber, incutir uma consciência política nos fiéis, que não viam prioridade nas batalhas legislativas, montar uma estrutura de apoio interna, elaborar uma estratégia eleitoral racionalizada centrada em um Candidato Oficial, a fim de garantir representantes, dentro outras ações de politização.

Por questões específicas da RCC, não ser hegemônica dentro do catolicismo e nem possuir uma estrutura hierárquica sólidas como algumas agremiações evangélicas, os candidatos carismáticos preferidos são homens e mulheres conhecidos pelo público católico ou figuras midiáticas como músicos e apresentadores. Todavia, a perspectiva eleitoral carismático-católica se concretizou com a fundação do Ministério de Fé e Política. O órgão se tornou responsável pelas formas de ação política do movimento promovendo diversas iniciativas de conscientização. Dessas destacamos a Cartilha de Fé e Política e a organização de eventos como o Encontro Nacional de Formação. O ministério defende também a interministerialização, um trabalho em conjuntos com as diferentes frentes do carismatismo católico a fim de garantir representação parlamentar.

Quando eleito, a atuação dos representantes da RCC é bem delimitada, concentrando-se em questões de moral reprodutiva e o histórico embate ao comunismo. Desse último, e centralidade se deu ao embate ao Partido dos Trabalhadores, com os políticos carismáticos atuando em constante oposição aos governos Lula e Dilma e tendo papel representativo no processo de impeachment desta última. 
Religare, ISSN: 19826605, v.16, n.1, agosto de 2019, p.170-206.

Relativo as questões de moral sexual, os carismáticos vêm atuando de maneira expressiva no Congresso, com o destaque para a posição à descriminalização do aborto. Sendo uma bandeira historicamente católica a Renovação Carismática atua praticamente como um movimento em si mesma, dentro e fora da política partidária (MARIZ, 2003). Com isso, houve uma maior confluência entre católicos carismáticos e evangélicos pentecostais. Por fim, entendemos que a participação política da RCC não deve analisada apenas como um movimento conflitivo ou similar a dos evangélicos pentecostais. $\mathrm{O}$ crescimento de seus representantes em termos partidários nas assembleias federal, estaduais e municipais, somado a forte presença de conservadorismo social, demonstra que essa participação pode aumentar os problemas de intolerância que o Brasil vive.

\section{Referências}

CARRANZA, Brenda. Renovação Carismática: origens, mudanças, tendências. Aparecida, Editora Santuário, 2000.

GIUMBELLI, Emerson. O Acordo Brasil-Santa Sé e as relações entre Estado, sociedade e religião. Porto Alegre. Ciencias Sociales y Religión, v. 13: n. 14: 119143, 2011.

LUNA, Naara. A Polêmica do Aborto e o $3^{\underline{o}}$ Programa Nacional de Direitos Humanos. Dados. Rio de Janeiro, v. 57, p. 239-277, 2014 a.

- A controvérsia do aborto e a imprensa na campanha eleitoral de 2010. Caderno CRH. UFBA., v. 27, p. 367-391, 2014 b.

- O direito à vida no contexto do aborto e da pesquisa com células tronco embrionárias: disputas de agentes e valores religiosos em um estado laico. Religião \& Sociedade , v. 33, p. 71-97, 2013.

MARIZ, Cecília. A opinião dos evangélicos sobre o aborto. In: FERNANDES, R. C. et al. (Org.). Novo nascimento: os evangélicos em casa, na igreja e na política. Rio de Janeiro: Iser, 1998. p.211-223.

MACHADO, Lia Zanotta. Os novos contextos e os novos termos do debate contemporâneo sobre o abroto. A questão de gênero e o impacto social das novas narrativas. In. Série antropológica, Brasília, n.419, 2008.

- Feminismos brasileiros nas relações com o Estado. Cadernos Pagu, Campinas, n.47, 2016. 
Religare, ISSN: 19826605, v.16, n.1, agosto de 2019, p.170-206.

MACHADO, Maria das Dores Campos. O tema do aborto na mídia pentecostal: notas de uma pesquisa. Revista Estudos Feministas, Florianópolis, v.8, n.1, p.200-211, 2000.

. Conflitos religiosos na arena política: o caso do Rio de Janeiro. Ciencias Sociales y Religión. Porto Alegre, ano 6, no 6, p. 31-49, 2004

. Política e Religião: a participação dos evangélicos nas eleições. Rio de Janeiro - Editora FGV, 2006.

- Aborto e ativismo religioso nas eleições de 2010. Revista Brasileira de Ciência Política. Brasília, n 7, p. 22-54, 2012

. Religião e Política no Brasil Contemporâneo: uma análise dos pentecostais e carismáticos católicos Religião, cultura e política. Religião \& Sociedade. Rio de Janeiro. v 35, n 2, p. 45-72. 2015.

Política, direitos humanos e aborto: uma análise das opiniões dos líderes pentecostais brasileiros. In. BIROLI, Flávia \& MIGUEL, Luis Felipe. Aborto e democracia. São Paulo, Alameda casa editorial, 2016, p. 17-46

MAINWARING, Scott. Igreja católica e a politica no Brasil: 1916-1985. São Paulo, Brasiliense, 1989.

MANDUCA, Vinicius. Atores políticos do pentecostalismo católico e evangélico paulista. Dissertação (Mestrado em Sociologia) - Programa de Pós Graduação em Sociologia, Universidade Federal de São Carlos, São Carlos. 2015.

MARIANO, Ricardo. Pentecostais e política no Brasil. Com Ciência Revista Eletrônica de Jornalismo Científico, Internet, v. 65. 2005.

Laicidade à brasileira: católicos, pentecostais e laicos em disputa na esfera pública. Civitas. Porto Alegre, v. 11, no 2, p. 238-258, 2011.

MARIZ, Cacília L. A Renovação Carismática Católica, uma igreja dentro da igreja? Civitas. Porto Alegre. 2003

MIGUEL, Luis Felipe. O direito ao aborto como questão política. In: BIROLI, Flávia \& MIGUEL, Luis Felipe. Aborto e democracia. São Paulo: Alameda Casa Editorial, 2016, pp 17-46

MIGUEL, Luis Felipe. Aborto e democracia. Estudos Feministas. (UFSC, Florianópolis). v 20, n 3, p. 657-672. 2012.

PIERUCCI, Antônio Flávio. \& PRANDI, Reginaldo. A realidade social das religiões no Brasil. São Paulo, Hucitec, 1996.

PRANDI, Reginaldo. Um sopro do espírito. São Paulo, Edusp 1997.

PROCOPIO, Carlos Eduardo. Carismáticos católicos e eleições no Brasil. Ciencias Sociales y Religión. V. 14, p. 75-99, 2012.

REIS, Marcos Vinícius Freitas. Política e Religião: A participação política dos católicos carismáticos do Brasil. Tese de doutorado em sociologia. São Carlos SP, UFSCar 2016.

RIBEIRO, Luís Felipe. Aborto e democracia. Revista Estudos Feministas, vol 20, no 3. Pp. 658. Santa Catarina. 2012. 
Religare, ISSN: 19826605, v.16, n.1, agosto de 2019, p.170-206.

ROSADO-NUNES, Maria José. Direitos, cidadania das mulheres e religião. Tempo Social. (USP, Impresso), v. 20, p. 67-81. 2000

O aborto sob o olhar da região: um objeto a procura de autor@s. In Estudos de Sociologia. (São Paulo), v. 17, p. 21-43. 2002.

SANTIN, Myriam Aldana. Aborto Legal: Igreja Católica e o Congresso Nacional. Publicações CDD: São Paulo, 2000

SILVEIRA, Emerson Sena da Silveira. Terços, "Santinhos" e Versículos: A relação entre católicos carismáticos e a política. Rever. São Paulo. 2008.

- Guerra Cultural Católica: política, espaços públicos e lideranças eclesiásticas. In: Emerson Sena da Silveira; Manoel Ribeiro de Moraes Junior. (Org.). Religião, Política e Espaço Público: discussões teóricas e investigações empíricas. 1ed.São Paulo: Fonte Editorial, 2015, v. 1, p. 11-48.

SOFIATI, Flávio Munhoz. Religião e Juventude: Os novos carismáticos. Ideias \&Letras, Aparecida: 2011.

SOUZA, André Ricardo de. O pluralismo cristão brasileiro. Caminhos, UFG, v. 10, no1, 2012, pp. 129-14. 2012

- Meandros da força política evangélica no Brasil. Cultura y Religión, v. 7, p. 117-128, 2013.

Recebido em 17/10/2018.

Aprovado em 16/07/2019. 